Open Access

\title{
Erratum to: Insulin improves memory and reduces chronic neuroinflammation in the hippocampus of young but not aged brains
}

Linda Adzovic ${ }^{1,2}$, Ashley E Lynn², Heather M D’Angelo ${ }^{1}$, Alexis M Crockett ${ }^{2}$, Roxanne M Kaercher ${ }^{1}$, Sarah E Royer ${ }^{2}$, Sarah C Hopp ${ }^{2}$ and Gary L Wenk ${ }^{1,2^{*}}$

\section{Erratum}

Following the publication of our article [1] we noticed that the western blot in Fig. 3c (Fig. 1c here) was incorrectly labelled. The S307-AKT band should instead be labelled T308-AKT. We have provided the correct figure here.

Received: 13 May 2015 Accepted: 13 May 2015

Published online: 07 August 2015

\section{Reference}

1. Linda A, Lynn AE, D'Angelo HM, Crockett AM, Kaercher RM, Royer SE, et al. Insulin improves memory and reduces chronic neuroinflammation in the hippocampus of young but not aged brains. J Neuroinflammation. 2015;12:63.

* Correspondence: wenk.6@osu.edu

'Department of Psychology, Ohio State University, 1835 Neil Ave, Columbus, $\mathrm{OH}$ 43210, USA

2Department of Neuroscience, Ohio State University, Columbus, OH 43210, USA

Submit your next manuscript to BioMed Central and take full advantage of:

- Convenient online submission

- Thorough peer review

- No space constraints or color figure charges

- Immediate publication on acceptance

- Inclusion in PubMed, CAS, Scopus and Google Scholar

- Research which is freely available for redistribution

Submit your manuscript at 


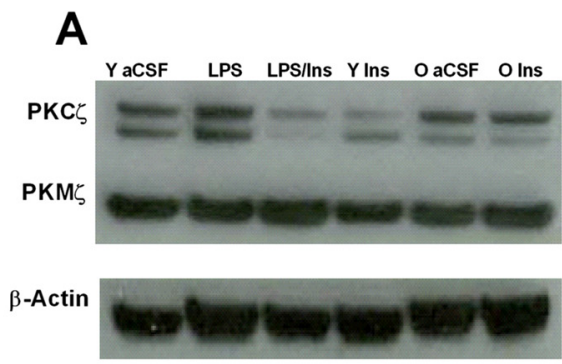

\section{C}

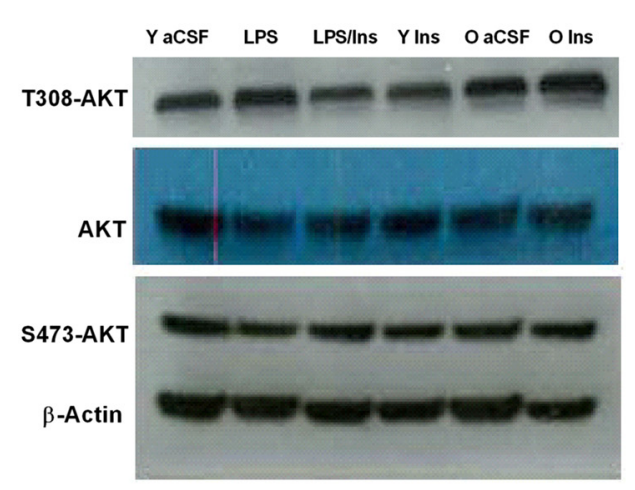

B

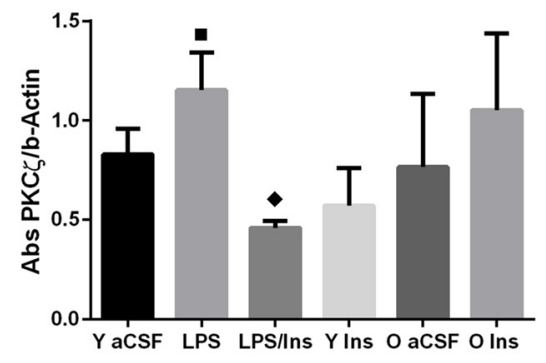

D
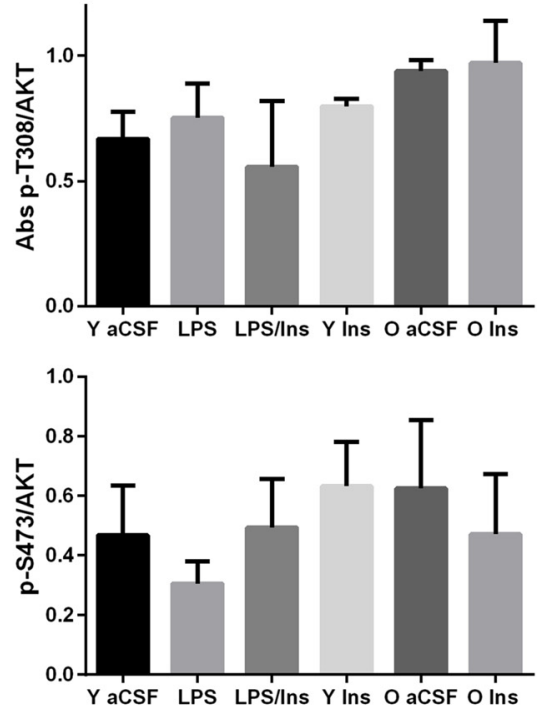

Fig. 3 Western blot analyses. The infusion of LPS into the fourth ventricle increased the protein level $(\mathbf{a}, \mathbf{b})$ of PKC, black square, $P<0.05$ versus aCSF. Insulin treatment reduced, black diamond, $P<0.001$, PKC levels as compared to LPS. (c, d) No significant changes were observed for $p$-AKT Threonine 308 or Serine 473 